2. Палій Г.К., Павлюк С.В., Палій Д.В., Назарчук О.А., Дудар А.О. Обгрунтування застосування антисептичних препаратів в системі профілактичних і лікувальних заходів (огляд літератури). Буковинський медичний вісник. 2018. № 22(4). С. 51-56.

3. Десятерик В.І. Фрагмент Всеукраїнського дослідження чутливості мікрофлори до антибактеріальних препаратів хворих з інтраабдомінальною хірургічною інфекцією / В.І. Десятерик, О.В. Котов, П.Г. Теліга, T.І. Савченко // Клінічна хірургія. - 2011. - № 6. - С. 38-40.

4. Палій Г.К.; Ковальчук В.П.; Фоміна Н.С. Характеристика сучасного арсеналу дезінфекційних засобів та проблеми дезінфектологiï. Biomedical and biosocial anthropology. 2014. № 22. С. 82-85.

5. Салманов А.Г., Марієвський В.Ф., Хобзей М.К. Резистентність бактерій до антисептиків та дезінфікуючих засобів. Украӥнський медичний часопис. 2010. № 6. С. 51-56.

6. Гудкова Е.И., et al. Формирование устойчивости к антисептикам и дезинфектантам возбудителей внутрибольничных инфекций и ее микробиологический мониторинг. Бел. мед. Журнал. 2003. № 3. С. 57-60.

7. Про затвердження методичних вказівок «Визначення чутливості мікроорганізмів до антибактеріальних препаратів» : наказ № 167 від 05.04.2007 p. [Електронний ресурс]. Міністерство охорони здоров’я України. Нормативно-директивні документи МОЗ України. Доступно: http://mozdocs.kiev.ua/view.php?id=6958

8. Красильников А.П. Справочник по антисептике. Минск: Вышейшая школа. 1995. - С. 470.

DOI https://doi.org/10.30525/978-9934-26-038-4-64

\title{
СТАН АТМОСФЕРНОГО ПОВІТРЯ ЕКОЛОГІЧНО НЕБЕЗПЕЧНОГО РЕГІОНУ
}

\section{Павленко О. I.}

кандидат медичних наук, старший дослідник, завідувач лабораторії промислових аерозолів

ДУ «Український науково-дослідний інститут промислової медицини» м. Кривий Ріг, Дніпропетровська область, Украӥна

Низький рівень здоров'я населення України, спричинений несприятливою екологічною та соціально-економічною ситуацією, нездоровим харчуванням кризою медичної галузі, зумовлює нагальну потребу ком- 
плексної реформи системи охорони здоров'я, включаючи сферу громадського здоров'я [1, с. 3].

Серед багатьох чинників, що впливають на довкілля та здоров'я населення, одне з головних місць посідають атмосферні забруднення [2, с. $31 ; 3$, с. $133 ; 4$, с. 9], яке у структурі економічних втрат валового внутрішнього продукту від смертності і захворюваності населення посідає друге місце [5, с. 3].

Мета дослідження - аналіз стану атмосферного повітря екологічно небезпечного регіону.

Матеріали та методи. Аналіз стану атмосферного повітря проведено за 2015-2019 pp. за середньодобовими, максимально разовими гранично допустимими концентраціями, середньомісячними концентраціями. Джерелом інформації були дані державної та відомчих систем моніторингу атмосферного повітря.

Дослідження виконано в рамках НДР «Наукове обгрунтування та розробка системи заходів з оцінки ризиків здоров'ю і життю працюючого населення еколого-небезпечного регіону» № ДР 0120U100999.

Результати. Проведений аналіз вмісту шкідливих хімічних речовин у атмосферному повітрі м. Кривий Ріг показав, що протягом року мали місце перевищення гранично допустимих максимально разових концентрацій пилу в $3,8-4,8$ рази $\left(1,90 \pm 0,19-2,39 \pm 0,22 \mathrm{мг} / \mathrm{M}^{3}\right)$ оксиду вуглецю 2,4 рази $\left(11,87 \pm 1,57 \mathrm{мг} / \mathrm{m}^{3}\right)$, діоксиду азоту в $1,4-2,75$ рази $\left(0,27 \pm 0,04-0,54 \pm 0,09 \mathrm{Mг} / \mathrm{m}^{3}\right)$, фенолу в $1,40-1,80$ рази $(0,013 \pm 0,002-$ $\left.0,017 \pm 0,003 \mathrm{мг} / \mathrm{m}^{3}\right)$, формальдегіду в $1,74-3,37$ рази $(0,062 \pm 0,004-$ $\left.0,117 \pm 0,006 \mathrm{мг} / \mathrm{m}^{3}\right)$. Але, як свідчать отримані дані, забруднення повітря м. Кривий Ріг протягом року є нерівномірним. Концентрації хімічних речовин в атмосферному повітрі, а відповідно їх сумарне забруднення в різні періоди року мають деякі відмінності. Значною мірою визначаючою умовою цих відмінностей $є$ метеорологічні умови в той чи інший період року. 3 метою розуміння основних залежностей між метеорологічними умовами та рівнями забруднення атмосферного повітря шкідливими хімічними речовинами у загальних рисах наведено найбільш важливі фізико-географічні особливості регіону, який досліджувався.

Так, поглиблений аналіз особливостей забруднення атмосферного повітря за сезонами року в основній групі дозволив визначити рівень та динаміку забруднення протягом річного проміжку часу.

Так, перевищення максимально разової концентрації формальдегіду по м. Кривий Ріг $\epsilon$ найвищим з травня по вересень та коливається від 2,46 до 3,37 ГДК, $\left(0,085 \pm 0,006-0,117 \pm 0,006\right.$ мг/м $\left.{ }^{3}\right)$ У період з січня по березень концентрація формальдегіду в атмосферному повітрі не перевищує ГДК. 3 жовтня по грудень - концентрація коливається у межах $1,03-1,51$ ГДК, $\left(0,033 \pm 0,06-0,052 \pm 0,005 \mathrm{мг} / \mathrm{m}^{3}\right)$. Середньомісячна концентрація формальдегіду протягом року значно перевищує ГДК та 
становить від 3,67 до 7,67 ГДК з середнім значенням по м. Кривий Ріг становить $0,013 \pm 0,005 \mathrm{Mг} / \mathrm{m}^{3}$ та у контрольній групі $0,0024 \pm 0,004 \mathrm{M \Gamma} / \mathrm{M}^{3}$.

Концентрація фенолу у атмосферному повітрі у період з жовтня по січень $є$ максимальною та становить $1,10-1,40$ ГДК $(0,010 \pm 0,001-$ $\left.0,013 \pm 0,002 \mathrm{мг} / \mathrm{M}^{3}\right)$, у квітні, липні, серпні, вересні - $\epsilon$ мінімальною та становить $0,8-1,0$ ГДК $\left(0,007 \pm 0,001-0,009 \pm 0,001 \mathrm{мг} / \mathrm{m}^{3}\right)$. Середньомісячна концентрація фенолу з лютого по травень становить 0,33 ГДК, а 3 червня по січень - 0,67 ГДК, що, відповідно, знаходиться у межах допустимих нормативів з середнім значенням по м. Кривий Ріг становить $0,0015 \pm 0,0005 \mathrm{Mг} / \mathrm{M}^{3}$ та у контрольній групі $0,0018 \pm 0,002 \mathrm{M \Gamma} / \mathrm{M}^{3}$.

Максимально разова концентрація діоксиду азоту $\epsilon$ найменшою 3 січня до березня та становить $0,7-0,95$ ГДК $(0,13 \pm 0,011-$ $\left.0,18 \pm 0,02 \mathrm{мг} / \mathrm{M}^{3}\right)$, а найвищою 3 квітня по грудень в межах $1,00-2,75$ ГДК $\left(0,19 \pm 0,024-0,54 \pm 0,087\right.$ мг/м $\left.{ }^{3}\right)$. Середньомісячна концентрація діоксиду азоту з жовтня по квітень становить 1,0 ГДК, а з травня по вересень - 1,25 ГДК з середнім значенням по м. Кривий Ріг становить $0,045 \pm 0,005 \mathrm{Mг} / \mathrm{M}^{3}$ та у контрольній групі $0,02 \pm 0,04 \mathrm{M \Gamma} / \mathrm{M}^{3}$.

Максимально разова концентрація оксиду вуглецю лише у березні

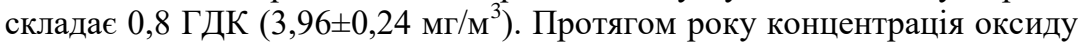

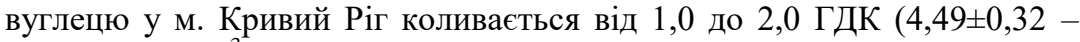
$\left.9,8 \pm 1,57 \mathrm{мг} / \mathrm{M}^{3}\right)$. Середньомісячна концентрація оксиду вуглецю 3 вересня по травень становить 0,67 ГДК, а 3 червня по серпень від 1,00 до 1,33 ГДК з середнім значенням по м. Кривий Ріг становить $2,5 \pm 0,05 \mathrm{Mг} / \mathrm{M}^{3}$ та у контрольній групі $0,3 \pm 0,1 \mathrm{Mг} / \mathrm{m}^{3}$.

Максимально разова концентрація пилу $є$ найменшою у грудні та січні та становить $1,80-2,40$ ГДК $\left(0,87 \pm 0,07-1,37 \pm 0,12\right.$ мг/м $\left.{ }^{3}\right)$. 3 лютого по листопад максимально разова концентрація пилу коливається від 3,0 до 4,8 ГДК $\left(1,45 \pm 0,09-2,39 \pm 0,22 \mathrm{мг} / \mathrm{M}^{3}\right)$. Середньомісячна концентрація пилу у січні становила 1,33 ГДК. У серпні та вересні - 4,0 ГДК 3 середнім значенням по м. Кривий Ріг становить $0,5 \pm 0,1 \mathrm{мг} / \mathrm{M}^{3}$ та у контрольній групі $0,105 \pm 0,2 \mathrm{Mг} / \mathrm{M}^{3}$.

Серед речовин забруднювачів, концентрація яких перевищувала ГДК протягом всіх сезонів року на першому місці $є$ пил, на другому формальдегід.

Максимальні концентрації пилу відмічались весною, що пов'язано 3 додатковим потраплянням іiї від природних джерел, частими штилями i слабими вітрами у приземному шарі атмосферного повітря.

Концентрації діоксиду сірки були найбільшими зимою та осінню, а в літній час - знижувались. Таке зниження можна пояснити закінченням опалювального сезону та зниженням вологості повітря.

Висновки. Таким чином, встановлені регіональні метеорологічні особливості територій, що досліджувались, які впливають на формування характеру і ступеня техногенного забруднення приземного шару 
атмосфери основної та контрольної групи. При цьому, визначення структури забруднення атмосферного повітря м. Кривий Ріг показало, що у різні пори року найбільша питома вага серед речовин забруднювачів складає пил, формальдегід, фенол, азоту діоксид, вуглецю оксид.

\title{
Література:
}

1. Пашинська С. Л. Наукове обгрунтування методичних підходів до інтегрального оцінювання стану навколишнього середовища та здоров'я населення : автореф. дис. ... канд. біол. наук : 14.02.01. Київ, 2017. $20 \mathrm{c}$.

2. Гребняк Н. П., Федорченко Р. А. Токсикологічні аспекти атмосферних забруднень в індустріальному місті. Довкілля та здоров'я. 2017. № 2. C. 31-35.

3. Петросян А. А., Черненко Л. М. Аналіз міжнародних законодавчих документів, які регулюють якість атмосферного повітря. Медичні перспективи. 2016. Т. XXI, № 1. С. 130-133.

4. Черниченко I. О., Баленко Н. В., Цимбалюк С. М., Осташ О. М. Про можливі механізми впливу атмосферних забруднень формальдегідом на формування захворюваності населення на рак щитоподібної залози. Довкілля та здоров 'я. 2016. № 2. С. 9-13.

5. Дзержинская Н. А. Гигиеническое обоснование критериев оценки воздействия многокомпонентного загрязнения атмосферного воздуха на здоровье населения : автореф. дис. ... канд. мед. наук : 14.02.01. Минск, 2017. 23 с.

DOI https://doi.org/10.30525/978-9934-26-038-4-65

\section{МЕТОДИ ПСИХОЛОГІЧНОЇ КОРЕКЦІї СИНДРОМУ COVID-CTPЕСУ}

\author{
Шпортун О. М. \\ доктор психологічних наук, дочент, \\ професор кафедри психологіі \\ КЗВО «Вінницька академія безперервної освіти» \\ м. Вінниця, Украӥна
}

На сьогодні дослідження того, як психологічно позначається і позначиться в майбутньому пандемія та карантин на людське життя, тривають. Однак, вже частково представлена низка цікавих даних з різних куточків світу, про те як саме реагує людство на COVID-19. Виявлено, що кожна культурна схема (національність) - має свої особливос- 